\title{
Nach Rohmilchgenuss an FSME erkrankt
}

\begin{abstract}
Nach den aktuellen FSME-Fällen durch Ziegenrohmilch in Baden-Württemberg sind viele Menschen verunsichert: Wie gefährlich sind Rohmilchprodukte, auch von Kühen? Schützt die FSME-Impfung auch in solchen Fällen? Wir sprachen mit dem Mikrobiologen und FSME-Experten Dr. Gerhard Dobler, München, der gerade mehrere größere Ausbrüche in der Slowakei untersucht hat.
\end{abstract}

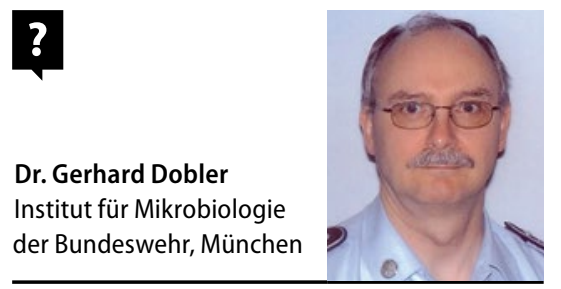

MMW: Im Landkreis Reutlingen sind zwei Personen an FSME erkrankt, nachdem sie Ziegenrohmilchprodukte zu sich genommen hatten. Muss man vor dem Verzehr solcher Produkte warnen? Dobler: Ziegen, die von einer FSME-Virus-infizierten Zecke gestochen wurden, können über etwa vier bis sechs Tage Virus ausscheiden. Die in dieser Zeit gewonnene Milch birgt eine hohe Infektionsgefahr. Das Virus wird offenbar in relativ großen Mengen in die Milch abgegeben; es ist auch in daraus hergestelltem Frischkäse enthalten. Der orale Infektionsweg über Milch scheint sehr viel effektiver zu sein als der Weg über den Zeckenstich. Wer infizierte Milch trinkt, erkrankt praktisch zu $100 \%$, während nach dem Stich einer infizierten $\mathrm{Ze}$ cke nur 30\% erkranken.

\section{MMW: Sind auch \\ Rohmilchprodukte von Kühen gefährdet?}

Dobler: Kuh- und Schafrohmilch enthalten offenbar weniger Virus als Ziegenrohmilch. Ich komme gerade aus der Slowakei zurück, wo es kürzlich ebenfalls zu einem FSME-Aus- bruch mit über 40 Erkrankten gekommen ist. Dort treten solche Ausbrüche jährlich zwischen fünf- und zehnmal auf. In der Slowakei wird oft Milch von verschiedenen Tierarten gemischt. In diesem Jahr war unter den Erkrankten auch eine vierköpfige Familie, die ausschließlich Rohmilch der eigenen Kuh getrunken hatte. Wir müssen davon ausgehen, dass sowohl Ziegen als auch Schafe und Kühe das FSME-Virus über die Milch übertragen können. Das gilt im Übrigen auch für den Menschen. Es gibt Hinweise, dass Frauen, die an FSME erkrankt sind, das Virus über die Muttermilch ausscheiden können.

MMW: Das heißt, man sollte das Stillen unterbrechen, wenn ein entsprechender Verdacht besteht? Dobler: Unbedingt.

\section{MMW: Wann stellt sich der Verdacht,} dass es sich um einen durch Rohmilch übertragenen Ausbruch handelt?

Dobler: Es wird immer dann auffällig, wenn mehrere Personen gleichzeitig erkranken. Das ist bei Zeckenstichen nicht wahrscheinlich.

\section{MMW: Ist der Infektionsweg} in Baden-Württemberg mittlerweile gesichert? Dobler: Hier war es eine Herde mit etwa 45 Ziegen, die sich auf einer mit infizierten Zecken befallenen Weide befunden haben. Den Stuttgarter Kollegen ist es gelungen, das Virus aus noch vorhandenen Milchprodukten zu isolieren.

\section{MMW: Ist die Gefahr jetzt gebannt?}

Dobler: Für diese Herde ja. Die ausgelieferte Ware wurde sofort zurückgerufen. Die Milch der Tiere darf nur pasteurisiert in den Handel gebracht werde. Rohmilchprodukte dürfen auf dem Hof bis auf Weiteres nicht mehr vertrieben werden.

MMW: Wie ist es mit Fleischprodukten von infizierten Tieren?

Dobler: Das rohe Fleisch wäre infektiös, weil sich das Virus in der Vermehrungsphase im Blut befindet. Sobald das Fleisch erhitzt ist, besteht keine Gefahr mehr.

MMW: Ist man durch eine FSME-Impfung vor einer durch Lebensmittel erworbenen Infektion geschützt?

Dobler: Das kann man eindeutig bejahen. Jemandem, der eine Vorliebe für Rohprodukte von Weidetieren aus dem süddeutschen Raum hat, würde ich in jedem Fall raten, sich impfen zu lassen.

Interview: Dr. Elke Oberhofer

\section{FSME-Fakten}

Das FSME-(Frühsommer-Meningo-Enzephalitis-)Virus ist im gesamten süddeutschen Raum endemisch. Laut Robert-Koch-Institut ist eine Übertragung des FSME-Virus durch infizierte Milch von Ziegen und Schafen in Deutschland sehr selten. Bei Produkten, die aus pasteurisierter Milch hergestellt werden, besteht keine Erkrankungsgefahr. 